\title{
DEHYDRINS PATTERNS IN COMMON BEAN EXPOSED TO DROUGHT AND WATERED CONDITIONS
}

\author{
PATRONES DE DEHIDRINAS EN PLANTAS DE FRIJOL EXPUESTAS A SEQUÍA Y RIEGO
}

\author{
M. Claudia Castañeda-Saucedo ${ }^{1 \star}$, Leobigildo Córdova-Téllez ${ }^{1}$, Ernesto Tapia-Campos ${ }^{3}$, \\ Adriana Delgado-Alvarado ${ }^{2}$, Víctor A. González-Hernández ${ }^{1}$, Amalio Santacruz-Varela ${ }^{1}$, \\ Herminia Loza-Tavera ${ }^{4}$, Gabino García-de-los-Santos ${ }^{1}$ and Martín Vargas-Suárez ${ }^{4}$
}

\begin{abstract}
${ }^{1}$ Postgrado de Recursos Genéticos y Productividad, Campus Montecillo, Colegio de Postgraduados. Km 36.5 Carretera México-Texcoco. 56230, Montecillo, Edo. de México, México. ${ }^{2}$ Programa en Estrategias para el Desarrollo Agricola Regional, Campus Puebla, Colegio de Postgraduados. Km 125.5 Carretera Federal México-Puebla. 72760, Puebla. ${ }^{*}$ Centro Universitario del Sur, Universidad de Guadalajara. Av. Enrique Arreola Silva \# 883. 49000, Col. Centro, Ciudad Guzmán, Jalisco. Tel 3415752222 Ext 46126. ${ }^{3}$ Centro de Investigación y Asistencia en Tecnología y Diseño del Estado de Jalisco, A.C. Normalistas 800. 44270, Colonia Colinas de la Normal, Guadalajara, Jalisco. ${ }^{4}$ Facultad de Química, Departamento de Bioquímica, Universidad Nacional Autónoma de México. Avenida Insurgentes Sur 3000, 04510. Coyoacán, D. F.
\end{abstract}

${ }^{*}$ Autor de correspondencia (csaucedo@colpos.mx)

\section{SUMMARY}

Drought is a major constraint for common bean (Phaseolus vulgaris L.) production in México. Dehydrins are constitutive or stressinduced proteins related with a protective role of membranes and macromolecules against denaturation, thus preventing loss of their function. In this work, seed production and patterns of dehydrins accumulation in leaves and pods were evaluated in common bean $\mathrm{cv}$. 'Otomi' subjected to drought, as compared with well-irrigated plants. Drought applied at pod formation and seed filling (SF) reduced yield up to $57 \%$. An antibody against a consensus sequence present in most dehydrins allowed for dehydrin identification. Two dehydrins of 82 and $73 \mathrm{kDA}$ turned up both in leaves and pods throughout all the evaluated conditions. Presumably, both dehydrins are constitutive in the 'Otomi' cultivar. These dehydrins showed higher expression than controls in leaves after $6 \mathrm{~d}$ of drought at seedling and SF stages, and in pods $6 \mathrm{~d}$ after drought had started at SF. Increased expression might provide better protection during early stages of seedling and seed development. Increments on 63, 36 and $22 \mathrm{kDa}$ dehydrin expression in pods at late SF might coincide with plant developmental programs, which prepare seed for desiccation. Dehydrins of 158, 54, 46, and 41 $\mathrm{kDa}$ were detected in pods $10 \mathrm{~d}$ after floral opening as a transient response to drought stress in SF. These results indicate dehydrins are relevant during plant development, as well as during drought stress.

Index words: Phaseolus vulgaris, dehydrins, drought, vegetative growth, pod development, seed filling.

\section{RESUMEN}

La sequía es el factor más limitante de la productividad de frijol (Phaseolus vulgaris L.) en México. Las dehidrinas son proteínas constitutivas o inducibles por diferentes tipos de estrés, relacionadas con la protección a membranas y macromoléculas contra la desnaturalización, que evitan la pérdida de función. En este trabajo se estudió el efecto de la sequía aplicada en diferentes etapas de desarrollo, sobre la producción de semilla y los patrones de acumulación de dehidrinas en hojas y vainas de frijol cv. 'Otomí', comparado con plantas irrigadas. La sequía aplicada durante el período de formación de vainas y llenado de semilla (SF), redujo hasta $57 \%$ el rendimiento. Las dehidrinas fueron identificadas con un anticuerpo que reconoce una secuencia consenso presente en la mayoría de ellas. Dehidrinas de 82 y $73 \mathrm{kDa}$ fueron detectadas en hojas y en vainas en todas las condiciones evaluadas, por lo que se consideran constitutivas del cultivar 'Otomí'. Estas dehidrinas presentaron mayor expresión que el control en hojas a los $6 \mathrm{~d}$ de sequía aplicada en los estadios de plántula y SF, y en vainas también a los $6 \mathrm{~d}$ de sequía aplicada en SF. Estos incrementos podrían ser necesarios para brindar mejor protección en etapas tempranas del desarrollo de la plántula y la semilla. Incrementos en dehidrinas de 63 , 36 y $22 \mathrm{kDa}$ observados en vainas durante la etapa de SF, podrían ser parte del programa de desarrollo de la planta encargado de preparar a la semilla para la desecación. En vainas se detectaron dehidrinas de $158,54,46$ y $41 \mathrm{kDa}$ a los $10 \mathrm{~d}$ después de la apertura floral, como una respuesta transitoria al estrés hídrico en SF. Estos resultados indican que las dehidrinas de frijol son relevantes durante el desarrollo de la planta y durante condiciones de estrés por sequía.

Palabras clave. Phaseolus vulgaris, desarrollo vegetativo, dehidrinas, desarrollo de vaina, llenado de semilla, sequía.

\section{INTRODUCTION}

Drought is a major environmental stress that limits crop productivity worldwide causing significant yield reductions (Gebeyehu et al., 2010). Under drought stress, plant responses are diverse. For example, common bean (Phaseolus vulgaris L.) exhibits morphological plasticity characterized by over-producing reproductive structures (Acosta et al., 2003); physiological changes, such as reduction of stomatal conductance and photosynthetic rates, have been recorded in kidney bean (Phaseolus vulgaris L.) (Miyashita et al., 2005); increased respiration in Arabidopsis (Shinozaki and Yamaguchi-Shinozaki, 2007) and sugar loss takes place in Arabidopsis and wheat (Tritricum aestivum L.) (Xue et al., 2008). At the subcellular level gene expression changes, induced by plant protection responses against environmental stress, have also been reported in response to drought. Some of these changes include synthesis of chaperons, dehydrins, osmotins, aquaporins, among other compounds, which directly act on stress tolerance, and synthesis of regulatory proteins such as transcription factors, kinases and enzymes of the phospholipids metabolism (Shinozaki and 
Yamaguchi-Shinozaki, 2007).

Dehydrins are biochemically classified as Group 2 LEA (late embryogenesis abundant) proteins (Close et al., 1989). Some of them are ABA-inducible and synthesized in different tissues of many plant families in response to several stresses, such as drought, freezing, salt stress, and even heavy metals (Hanin et al., 2011). Some dehydrin proteins play important protective roles during cellular dehydration, but their precise function remains unclear (Tripepi et al., 2011). It has been proposed that dehydrins play specific protective roles against water stress in plant cells, by preventing denaturation of macromolecules (Sun et al., 2009) and safeguarding membrane structure (Mouillon et al., 2008).

In Arabidopsis thaliana, overexpression of the wheat dehydrin DHN-5 contributed to enhanced osmotic stress tolerance and preservation of in-vitro enzyme activities, which protected the plant from adverse effects induced by heating (Brini et al., 2010). Dehydrin synthesis and accumulation occur not only as a response to stress, but they also take part in pre-programmed events during later developmental stages of seed development in orthodox-type seeds (Close, 1996; Tripepi et al., 2011; Jiménez-Bremont et al., 2012). At these stages, different molecular weight dehydrins have been found in seeds of Arabidopsis (Olvera-Carrillo et al., 2010), barrel clover (Medicago trunculata Gaertn.) (Chatelain et al., 2012), barley (Hordeum vulgare L.), onion (Allium cepa L.), cotton (Gossypium hirsutum L.), tomato (Solanum lycopersicum Mill.), radish (Raphanus sativus L.), cowpea (Vigna unguiculata L.), cucumber (Cucumis sativa L.), pine nut (Pinus spp.), ginkgo (Ginkgo biloba L.) (Close et al., 1993), and common bean (Colmenero-Flores et al., 1999). Additionally, dehydrins are constitutively expressed in vegetative organs like leaves during normal growth conditions (Rorat et al., 2006).

Common bean is the most important source of protein for direct human consumption in the world, most particularly in Latin America and in Eastern and Southern Africa. Bean seed is also a source of vitamins, dietary fiber, and minerals, and it is free of unsaturated fatty acids (De la Fuente et al., 2011). Latin America and Africa contribute nearly 8 million tons to the approximately 12 million metric tons produced annually worldwide (FAO, 2005).

In México, common bean is sown in 1.5 million ha (OEIDRUS, 2011), mainly at the highland Northern plains, located between 1800 and 2200 masl, under rainfed conditions with less than $450 \mathrm{~mm}$ of rain per year (González and Bernsten, 2005). Nuñez et al. (2005) have reported that drought stress significantly reduces seed yield (by up to 60 $\%$ ) in bean production. In developing countries, most of the common bean is produced under low-input agriculture on small-scale farms (Jones, 1999). Beans produced by resource-poor farmers are more vulnerable to abiotic stresses, such as drought and low soil fertility (Miklas et al., 2006).

Although differential dehydrin expression has been shown to change in response to drought in several species, few reports on dehydrin expression in Phaseolus vulgaris $\mathrm{L}$. are available. Since dehydrin presence has been associated with stress tolerance, they have been proposed as markers for selecting drought tolerant plants (López et al., 2002). This work profiled the presence of dehydrins in leaves and pods of cv. 'Otomí', a Mexican semi-arid highland bean cultivar, classified as water stress-adapted during the vegetative and reproductive stages.

\section{MATERIALS AND METHODS}

Plant growth conditions, drought stress treatments and yield evaluation. Seeds of cv. 'Otomí' were sown in 6 $\mathrm{L}$ plastic bags filled with a 2:2:1:1 (v/v) mixture of soil:river sand:peat moss:agrolite. The 'Otomí' cultivar was selected because it has shown good agronomic performance at semi-arid highlands regions of México (Schneider et al., 1997). Experiments were setup under greenhouse conditions at Montecillo, Texcoco, State of México, located at $19^{\circ}$ $54^{\prime} \mathrm{N}, 98^{\circ} 54^{\prime} \mathrm{W}$ and 2250 masl. Field capacity (FC) and permanent wilting point (PWP) for the substrate were determined via the pressure pot and pressure membrane protocols (Castellanos et al., 2000; Insunza et al., 2010); a moisture retention curve was generated with these data (data not shown).

Irrigated (I) plants were maintained at FC (22.5\% of moisture content) by daily replenishing the water lost via evapotranspiration in each pot. Daily water loss was determined by pot weight and the estimated values from the moisture retention curve. Drought stress treatments started when the substrate reached PWP (11.5\% of moisture content). Daily irrigation was halted and resumed $10 \mathrm{~d}$ later to restore FC conditions in each pot.

For dehydrin analyses in leaves, four separate drought stress treatments were imposed at the beginning of four specific developmental stages: 1 ) seedling stage (S), plants with three leaves; 2) flowering stage (F); 3) pod formation (PF), floral opening (approximately $4 \mathrm{~d}$ after flowering); and 4 ) seed filling period (SF), $11 \mathrm{~d}$ after floral opening (dafo). According to Fernández et al. (1991), the corresponding bean developmental stages were 1) V4; 2) R6; 3) R7; and 4) R8.

For dehydrin analyses in pods, samples from plants under water stress at PF and SF stages (Figure 1) were taken. Control samples were taken from plants irrigated (I) throughout the growing season, one for dehydrin expression in leaves 
and another for dehydrin expression in pods.

Both irrigated (I) and drought stressed treatments (D) were distributed under a complete randomized blocks design with three replications. The experimental unit was a group of 20 pots, each with one plant per pot.

During the growing season, temperature and relative humidity in the greenhouse varied from 17 to $23{ }^{\circ} \mathrm{C}$ and from 57 to $75 \%$, respectively. Leaf and pod water potentials $\left(\mathrm{Y}_{1}\right.$ and $\left.\mathrm{Y}_{\mathrm{p}}\right)$ were determined at each stage with a Scholander pump, model A699® (Soil Moisture Equipment Corp. Santa Barbara, CA, USA). At the end of the season, the following variables were measured: dry seed yield per plant (g), pods per plant, seeds per plant, and seeds per pod. Data were analyzed with the Statistical Analysis System software (SAS, 1989-1996, version 6.12), by ANOVA and multiple mean comparisons with the Tukey test $(\alpha=0.05)$.

Collected tissues. Mature leaves were collected from irrigated and non-irrigated plants at 0,6 , and $10 \mathrm{~d}$ of water withholding at the S, F, PF, and SF stages. Pods were collected at 4, 7, and 10 dafo (4, 7, and $10 \mathrm{~d}$ without watering) for the PF stage; and at 14, 18, 22 and 30 dafo (3 and $7 \mathrm{~d}$ of stress, and 1 and $7 \mathrm{~d}$ of rehydration after the $10 \mathrm{~d}$ period of water withholding, respectively) for SF stage (Figure 1). All samples were frozen in liquid nitrogen and stored at $-20{ }^{\circ} \mathrm{C}$ until analyzed.

Protein extraction and dehydrin identification by Western blot. Tissue samples from each tissue, $250 \mathrm{mg}$ fresh weight, were ground up in a mortar with liquid nitrogen and mixed with $1 \mathrm{~mL}$ of extraction buffer $(20 \mathrm{mM}$ Tris$\mathrm{HCl}$ [pH 7.5], $0.5 \mathrm{M} \mathrm{NaCl})$. The extract was centrifuged at $14000 \mathrm{Xg}$ for $20 \mathrm{~min}$ at $4{ }^{\circ} \mathrm{C}$, and the supernatant collected into Eppendorf vials. Then vials were boiled in a water bath for $15 \mathrm{~min}$, placed on ice for $10 \mathrm{~min}$, centrifuged again for $20 \mathrm{~min}$, and the supernatant stored at $-20{ }^{\circ} \mathrm{C}$ until analysis. Protein was quantified by the Bradford method (1976), using bovine serum albumin as standard.

For Western blot analysis, samples with $10 \mu \mathrm{g}$ of total protein extracted from leaves and pods from I and D plants were subjected to SDS-PAGE (10\% w/v acrylamide) using Mini Protean II ${ }^{\circledR}$ cells (Bio-Rad), and then transferred to nylon membranes (11467-065, Gibco BRL) in the blotting

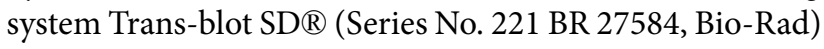
(Towbin et al., 1979). Membranes were blocked in $5 \%$ (w/v) non-fat dried milk in TBS-T buffer $(20 \mathrm{mM}$ Tris-base [pH 7.6], $137 \mathrm{mM} \mathrm{NaCl}, 0.1 \%$ Tween 20) during $1 \mathrm{~h}$. The membrane was then incubated overnight with the anti-dehydrin primary antibody, at a 1:1000 dilution. The antibody was raised against the conserved consensus, carboxyl-end, oligo-peptide sequence TGEKKGIMDKIKEKLPGQH, corre- sponding to dehydrin proteins (Close et al., 1993), kindly provided by Dr. T. J. Close. Reactive bands were detected with a secondary antibody conjugated horseradish peroxidase (Goat anti-Rabbit IgG $[\mathrm{H}+\mathrm{L}]-\mathrm{HRP}$ conjugated, ZYMED).

The resulting protein-antibody complex was detected by a chemiluminescent detection system (ECL, Amersham). Western blots were repeated at least three times. Band density, corresponding to proteins detected with the anti-dehydrin antibody, was obtained in optical density units (ODU) per $\mathrm{mm}^{2}$ using the analytical program Quantity One $42.1{ }^{\circledR}$ (Bio Rad), and a relative intensity band comparison was performed. Data were analyzed with the SAS software (version 6.12), through ANOVA and Tukey tests $(\alpha=0.05)$.

\section{RESULTS AND DISCUSSION}

Water status in leaves and pods. At the end of the drought stress treatments, the average leaf water potentials for water stressed plants $\left(\mathrm{Y}_{1}\right)$ were $-1.1 \mathrm{MPa}$ at flowering (F), -1.1 MPa at pod formation (PF), and $-1.2 \mathrm{MPa}$ at seed filling (SF), compared to $-0.64 \mathrm{MPa}$ at the same stages under irrigated conditions (I). Pod water potentials $\left(\mathrm{Y}_{\mathrm{p}}\right)$ were -1.23 and $-1.52 \mathrm{MPa}$ for water stressed pods at PF and SF, respectively, while in watered conditions it was $-0.73 \mathrm{MPa}$. According to Guida et al. (2004), a mild drought stress for common bean corresponds to $\mathrm{Y}_{1}=-0.9 \mathrm{MPa}$ during the preflowering stage. The stress level achieved in the present study is between moderate and severe.

Compared to controls, drought stress caused seed yield losses of $1.2 \mathrm{~g}(10 \%), 7 \mathrm{~g}$ (57\%), and $6.1 \mathrm{~g}$ per plant (50 $\%)$ when the stress was applied at the F, PF and SF stages, respectively (Table 1). Water stress caused highest yield losses when applied during pod formation and seed filling. These results might be a result of drought-related downregulation of several basic biosynthetic functions, including photosynthesis, photorespiration, and amino acid and carbohydrate metabolism, as reported by Neslihan et al. (2002) and Cuellar et al. (2008).

When water was withheld at PF and SF stages, yield losses were closely associated to reductions in the number of seeds per plant, pods per plant, and seeds per pod. Similarly, Gebeyehu et al. (2010) reported that pods per plant and seeds per pod are the most affected yield components in droughttreated bean plants. The smaller yield decrease observed at water stressed plants at the F stage can be attributed to a 30-day delay in flowering; plants partially compensated the lower production by growing new pods and seeds after the stress period.

Dehydrins in leaves. In bean leaves, two dehydrin-like 


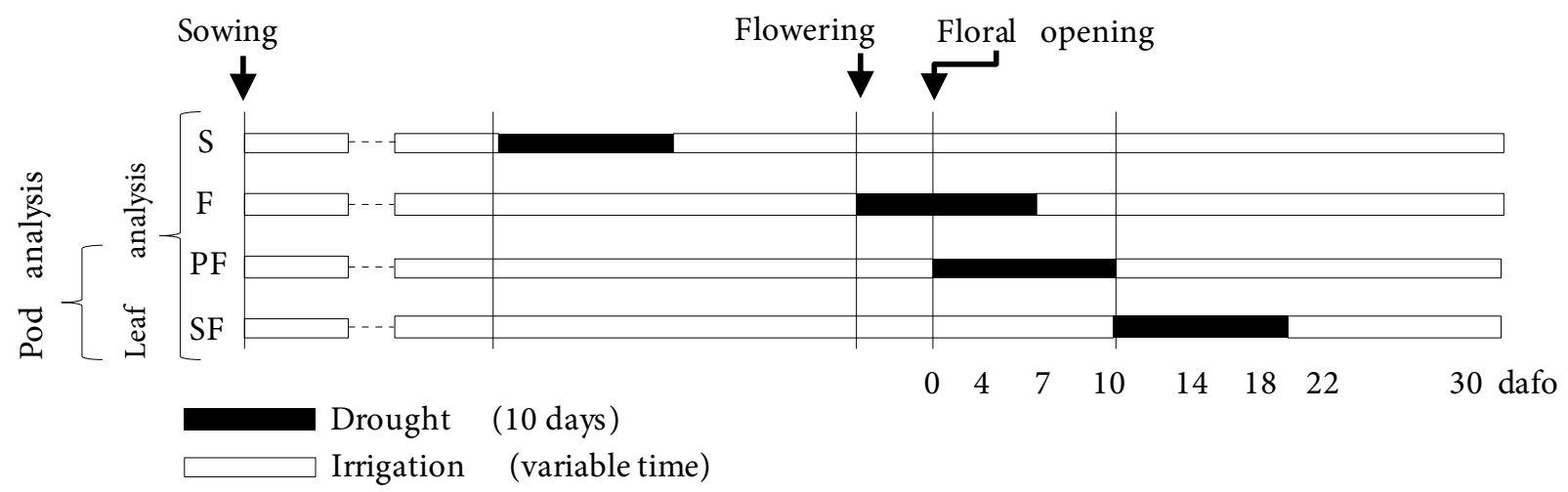

Figure 1. Application timing of the drought treatments imposed to bean plants. The substrate was maintained at field capacity during the irrigated period. Drought stress started when substrate reached the PWP (11.5 \% of moisture content), and was kept in this condition for 10 days by withholding irrigation (dark bars), at the phenological stages indicated (S, seedling; F, flowering; PF, pod formation; SF, seed filling). After drought stress, irrigation was resumed. Leaf tissue samples were taken at 0,6 and 10 days from plants submitted to the four different drought treatments. Pod tissue samples were collected at the indicated days after floral opening (dafo) from drought-stressed plants during pod formation (PF) and seed filling (SF).

Table 1. Seed yield and its components in common bean cv. 'Otomí' under irrigation (I), and drought-stressed at flowering (F), pod formation (PF), and seed filling (SF).

\begin{tabular}{lcccc}
\hline Treatment & Yield (g/plant) & Pods per plant & Seeds per plant & Seeds per pod \\
\hline $\mathrm{I}$ & $12.2 \mathrm{a}$ & $8.8 \mathrm{~b}$ & $35.0 \mathrm{a}$ & $3.97 \mathrm{a}$ \\
$\mathrm{F}$ & $11.0 \mathrm{~b}$ & $11.1 \mathrm{a}$ & $36.4 \mathrm{a}$ & $3.27 \mathrm{~b}$ \\
$\mathrm{PF}$ & $5.2 \mathrm{c}$ & $5.3 \mathrm{c}$ & $16.2 \mathrm{~b}$ & $3.07 \mathrm{~b}$ \\
$\mathrm{SF}$ & $6.1 \mathrm{c}$ & $5.9 \mathrm{c}$ & $19.2 \mathrm{~b}$ & $3.30 \mathrm{~b}$ \\
$\mathrm{MSD}_{0.05}$ & 1.114 & 1.431 & 5.073 & 0.294 \\
\hline
\end{tabular}

Means with the same letter in a column are not statistically different (Tukey, 0.05). MSD = minimum significant difference.

proteins of 82 and $73 \mathrm{kDa}$ were detected by Western blot. These dehydrins were detected in plants grown under water stress and control conditions at all analyzed phenological stages (Figure 2). Therefore, both dehydrins appear to be constitutive in leaves of the 'Otomí' cultivar. This behavior might indicate adaptation to drought, since this cultivar has been selected for Mexican semi-arid highlands regions (Martínez et al., 2008). Constitutive expression of dehydrin DHN1 has been detected in vegetative tissues of Vitis vinifera and wild $V$. yeshanensis, species that have shown tolerance to drought and cold, as well as moderate resistance to powdery mildew under normal growth conditions (Yang et al., 2012).

Some differences in the amount of both proteins were detected on the $6^{\text {th }}$ and $10^{\text {th }}$ day of stressed plants in any stage, but only on the $6^{\text {th }}$ day of the S and PF stages the amount of these proteins was higher in stressed plants than in irrigat- ed plants (Figure 2). It might be possible that the protective role of these dehydrins against drought was more needed at these stages of development when seedlings and seeds are being formed.

Under irrigation, the levels of the 82 and $73 \mathrm{kDa}$ proteins in leaves tended to diminish from one developmental stage to the next one ( $\mathrm{S}$ to F, F to PF, and PF to SF), although they also showed some increases in each stage. These patterns strongly suggest that the expression of these dehydrins respond to developmental cues. In common bean seedlings, Colmenero-Flores et al. (1999) observed accumulation of PvLEA-18 gene, of their transcripts and of its $14 \mathrm{kDa} L E A$ encoded protein, in different organs regardless of irrigation. The authors suggested that accumulation of PvLEA-18 transcript is probably modulated by an ABA-mediated mechanism during water stress and by other hormone-mediated mechanism involved in growth induction. 

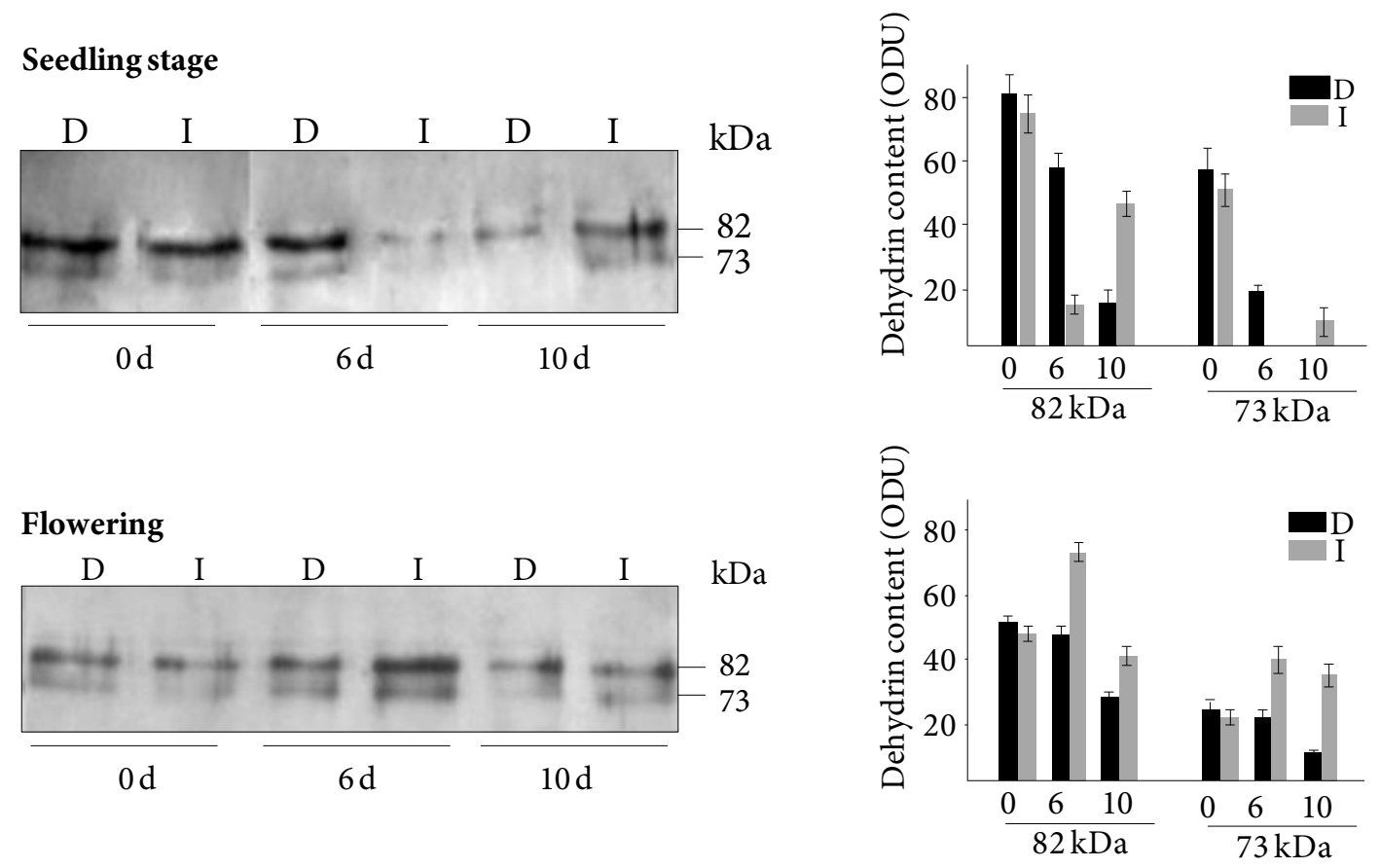

Pod formation
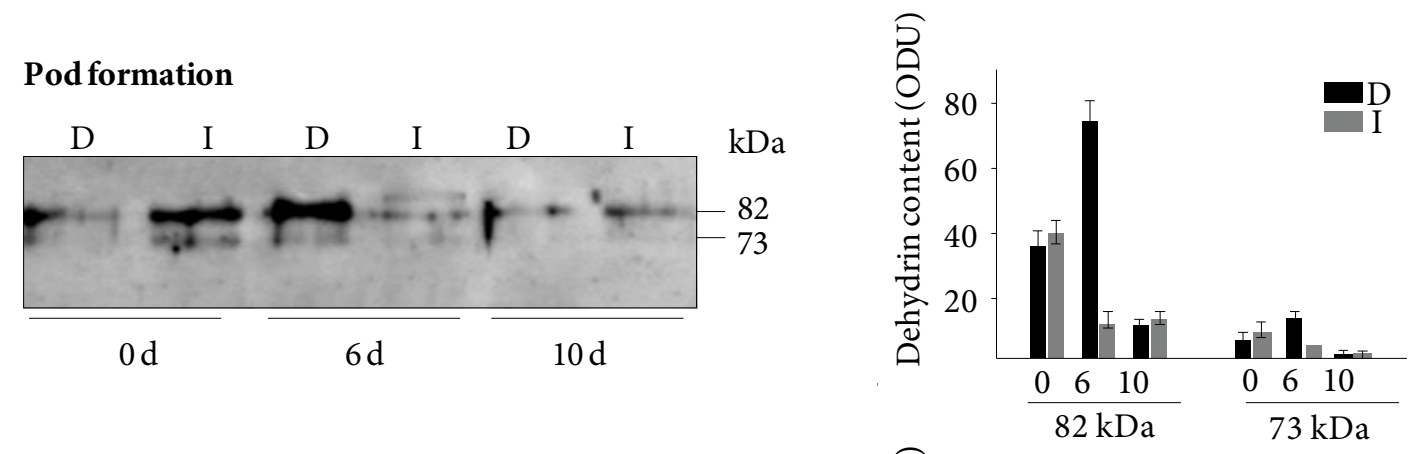

Seed filling
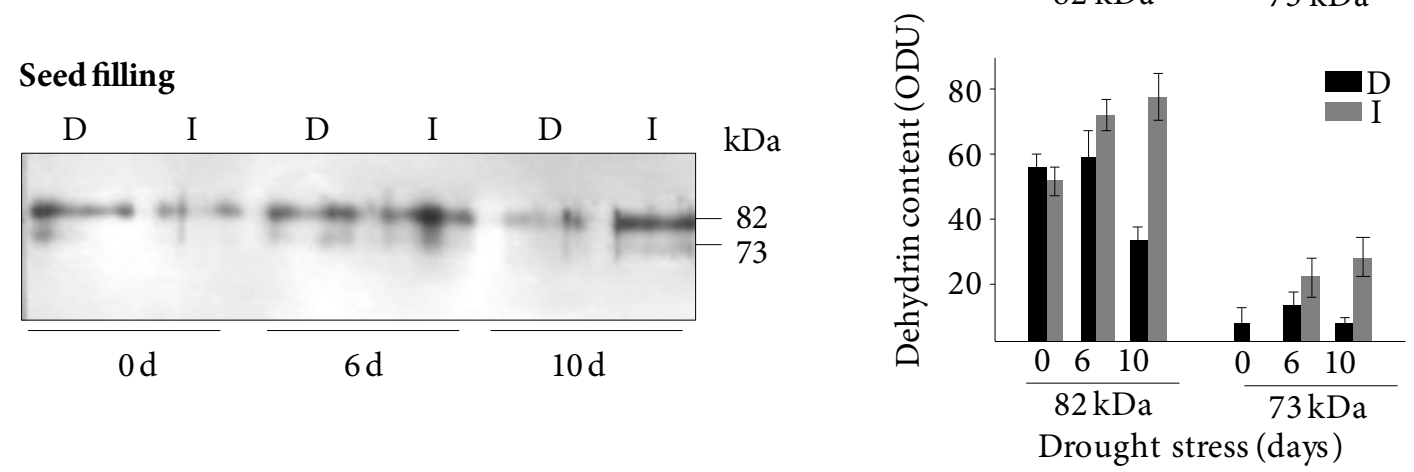

Figure 2. Western blots (left panels) and densitometries (right panels) of dehydrin proteins in leaves of common bean cv. 'Otomi' at different drought stress treatments. Proteins were extracted from leaves at 0, 6 and 10 days in drought-stressed treatments (D) or from irrigated (I) plants. Drought treatments were applied at the developmental stages of seedling, flowering, pod formation and seed filling. Proteins $(20 \mathrm{mg}$ per lane) were resolved in a PAGE-SDS gel, blotted onto nylon membranes, and decorated with an antibody against a consensus dehydrin amino acid sequence. Dehydrin content was quantified by densitometry, and columns graphs constructed. ODU: Optical density units $/ \mathrm{mm}^{2}$. Vertical lines on the bars are standard errors $(\mathbf{n}=3)$. 
The levels of two dehydrin polypeptides of 40 and $42 \mathrm{kDa}$ in protein extracts from Oleae europaea leaves (Tripepi et al., 2011) and of 31 and $40 \mathrm{kDa}$ in leaves of warm-season Bermuda grass (Cynodon dactylon L.), increased when the plants were exposed to water stress (Hu et al., 2010). In grapevine, dehydrins DHN1, DHN2, DHN3, and DHN4 belong to a dehydrin family that might be constitutively expressed in vegetative tissues, induced during embryogenesis or by drought and other stresses, depending on the member; thus, each dehydrin exhibits a very distinctive expression pattern, pointing to versatility in dehydrin responsiveness within a single plant species (Yang et al., 2012).

The levels of the 82 and $73 \mathrm{kDa}$ dehydrin proteins in bean leaves tended to diminish as water stress advanced, in most stages studied. Decline in the leaf dehydrins accumulation of 25 and $40 \mathrm{kDa}$ has also been reported in six varieties of soybean when grown under drought stress conditions (Laras et al., 2013). Moreover, other protective proteins synthesized in response to osmotic stress induced by mannitol, such as heat shock proteins and the dnaK-type molecular chaperone, also decreased their expression after the first 24 $\mathrm{h}$ of mannitol treatment; this behavior suggests that these proteins may be effective at the beginning of the stress period (Zhang and Comatsu, 2007).

In general, development and drought stress affected 82 and $73 \mathrm{kDa}$ leaf proteins accumulation similarly (Figure 2 ). The expression profile of a dehydrin gene family in apple (Malus domestica Borkh.) revealed that nine MdDHN dehydrins are selectively expressed as groups in different tissues, under normal growing conditions. Under drought treatment, most members were up regulated more than 100 -fold, whereas the rest were induced less than 10-fold (Liang et al., 2012). It has been suggested that selective expression of DHN1, DHN2, DHN3, and DHN4 proteins in grapevine tissues is coordinated by cis-regulatory elements in the promoter region of their genes (Yang et al., 2012). Thus, the 82 and $73 \mathrm{kDa}$ dehydrins identified in bean leaves might be members of a protein family and functionally related to each other, implying that they might have similar cis-regulatory regions at their genes promoters.

Dehydrins in pods. Dehydrin accumulation during pod development was analyzed in response to drought stress applied at two different stages, pod formation and seed filling (Figure 1). Anti-dehydrin antibody revealed nine protein bands of $158,82,73,63,54,46,41,36$, and $22 \mathrm{kDa}$ (Figure 3), expressed at different times during pod development. Reports indicate that several dehydrin sizes are expressed across species grown under drought stress; for example, 25 and $60 \mathrm{kDa}$ proteins in barley, 40 and 60 $\mathrm{kDa}$ proteins in maize (Close et al., 1993), $63 \mathrm{kDa}$ protein in wheat, rice (Oryza sativa L.), and maize (Borovskii et al., 2002), and $50 \mathrm{kDa}$ protein in Quercus ilex (Turco et al., 2004). However, the tissue, as well as the extent of water deficit and the genotypic level of drought tolerance ( $\mathrm{Hu}$ et al., 2010), determine type, size, and accumulation level of dehydrins (Close et al., 1993).

Proteins of 82 and $73 \mathrm{kDa}$ (the same ones detected in leaves), consistently appeared under all the analyzed conditions, possibly indicating they are constitutive proteins in leaves and pods (Figure 3). A distinct developmentdependent accumulation of 82 and $73 \mathrm{kDa}$ dehydrins was observed (Figure 4B, 4C). Drought stress applied at the PF stage caused accumulation reductions at 4 and $10 \mathrm{~d}$ of water withholding, corresponding to 4 and $10 \mathrm{~d}$ after floral opening (dafo). In contrast, a sharp increase in $82 \mathrm{kDa}$ protein at $7 \mathrm{~d}$ of water deprivation ( $7 \mathrm{dafo}$ ) was detected (Figure 4B). Large increments at the beginning of the seed filling period (14 dafo), followed by decreases and stable levels later on, were observed independently of the water treatment for both proteins (Figure 4B, 4C).

When drought stress was applied at SF stage, it caused a $40 \%$ decrease in $82 \mathrm{kDa}$ protein level after $4 \mathrm{~d}$ of treatment (14 dafo), whereas an important increase of $58 \%$ occurred after $8 \mathrm{~d}$ of treatment (18 dafo) (Figure 4B). Also at this stage, the level of $73 \mathrm{kDa}$ protein diminished around $30 \%$ after $3 \mathrm{~d}$ of stress. During recovery of water stresses imposed at the PF or SF stages both proteins matched the control levels (Figure 4). A decrease in the content of dehydrins after drought stress is not uncommon. Under severe stress, degradation of pre-existing dehydrins can take place in association with increases in free amino acids, as well as a reduction of total protein synthesis, and ribosomes dissociation (Rodríguez et al., 2003; Saladin et al., 2003).

The level of $36 \mathrm{kDa}$ dehydrin was affected by drought stress applied at the PF stage on the $7^{\text {th }}$ day, causing a 15fold increase over the control (Figure $4 \mathrm{H}$ ). Consequently, like in leaves, a protective role of 82 and $36 \mathrm{kDa}$ dehydrins against drought in pods would be more evident at a specific developmental stage and time after the water stress period application: $7 \mathrm{~d}$ in pod formation and $8 \mathrm{~d}$ in seed filling. Dehydrins might be functioning as stabilizers and protectants both in leaves and pods of stressed plants (Laras et al., 2013), by interlinking themselves with intracellular macromolecules and covering them with a layer of cohesive water preventing protein precipitation (Close, 1996), or by serving as space fillers to prevent cellular collapse at low water activities (Tunnacliffe and Wise, 2007; Hanin et al., 2011). Thus, the accumulation of the 82,73 , and $36 \mathrm{kDa}$ dehydrins might contribute to dehydration tolerance in common bean plants. In Poa bulbosa and apple, dehydrins that show constitutive accumulation can also be stimulated by water stress (Volaire et al., 2001; Liang et al., 2012). 


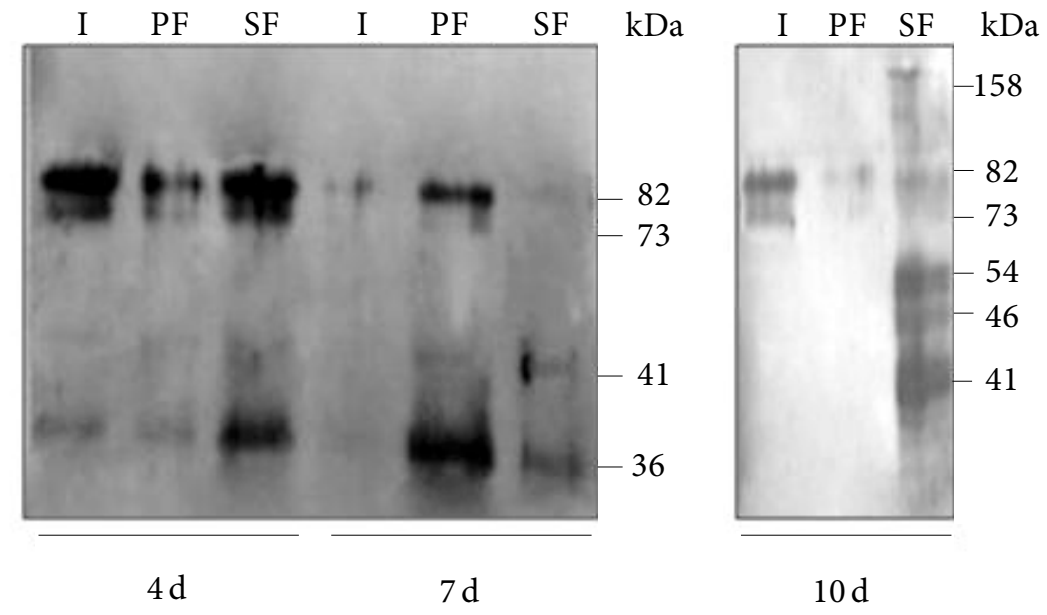

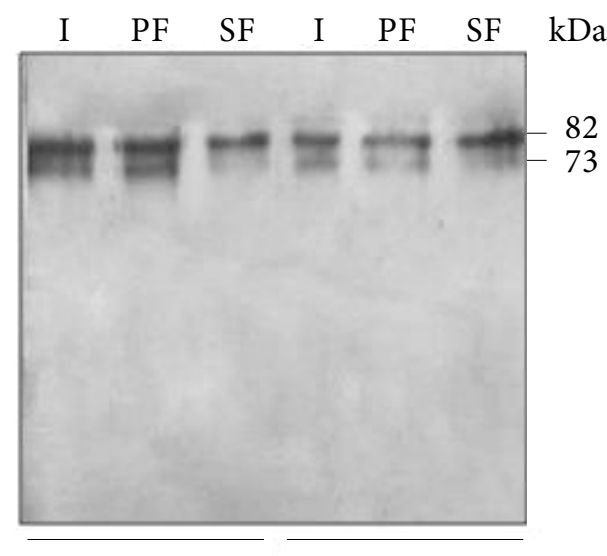

$14 \mathrm{~d}$ $18 \mathrm{~d}$

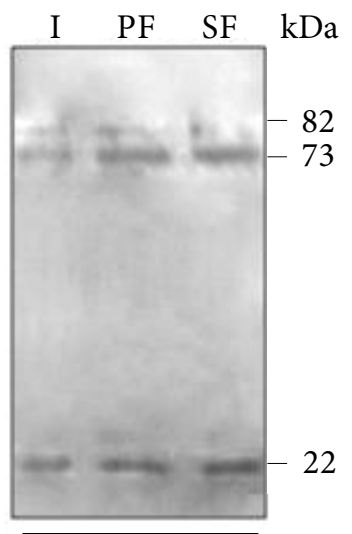

$22 \mathrm{~d}$

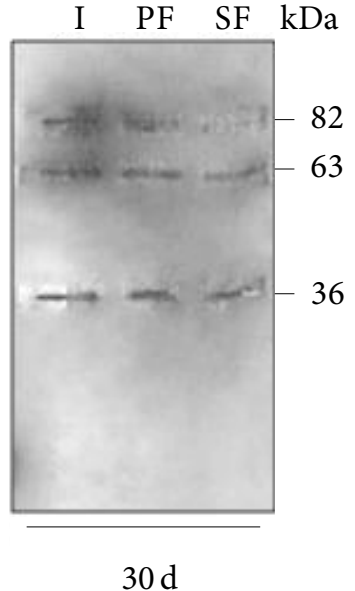

$30 \mathrm{~d}$

Figure 3. Western blots of dehydrin proteins detected in pods of common bean cv. 'Otomi' at different drought stress treatments. Proteins were extracted from pods of watered (I) and drought stress plants, at pod formation (PF) and seed filling (SF) stages. Samples were taken at 4, 7, 10, 14, 18, 22 and 30 days after floral opening (d). Proteins ( $20 \mathrm{mg}$ per lane) were resolved in a PAGE-SDS gel, blotted into nylon membranes, and decorated with an antibody against dehydrin consensus sequence.

Both irrigated and water stressed bean plants showed that their levels of three dehydrins considerably increased at later stages of pod development, without any difference between water treatments. For example, the 63 and $36 \mathrm{kDa}$ dehydrins accumulated at $30 \mathrm{dafo}$, while the $22 \mathrm{kDa}$ protein accumulated at 22 dafo (Figure 4D, 4H, 4G). On these dates, regular watering had been resumed, so that the regulation in the expression of these dehydrins would completely rely on a developmental program and not on drought. The late expression of these proteins during pod development suggests that they might be involved in the acquisition of desiccation tolerance by seeds. The presence of diverse dehydrins at this developmental stage has been widely documented for different plant species (Wechsberg et al., 1994; Bhattarai and Fettig, 2005; Yang et al., 2012).
Expression of proteins of $158 \mathrm{kDa}, 54 \mathrm{kDa}, 46 \mathrm{kDa}$, and $41 \mathrm{kDa}$ in pods of plants submitted to drought stress at SF, precisely at $10 \mathrm{dafo}$, was peculiar since plants were not yet at the drought stress phase (Figure 4A, 4E, 4F, 4G). However, because the beginning of stress was marked as the day the substrate reached PWP, 11 dafo or $2 \mathrm{~d}$ after irrigation had been halted, it is possible that plants were already stressed, previously to the SF period; at early stages of embryogenesis, they synthesized these specific proteins to protect the embryo against drought stress.

The fact that strong and clear increase in dehydrin synthesis in response to drought stress in the 'Otomí' cultivar was not found does not necessarily mean that the presence of other dehydrins is unrelated to water stress resistance. Analysis of bean cultivars adapted to irrigated fields 


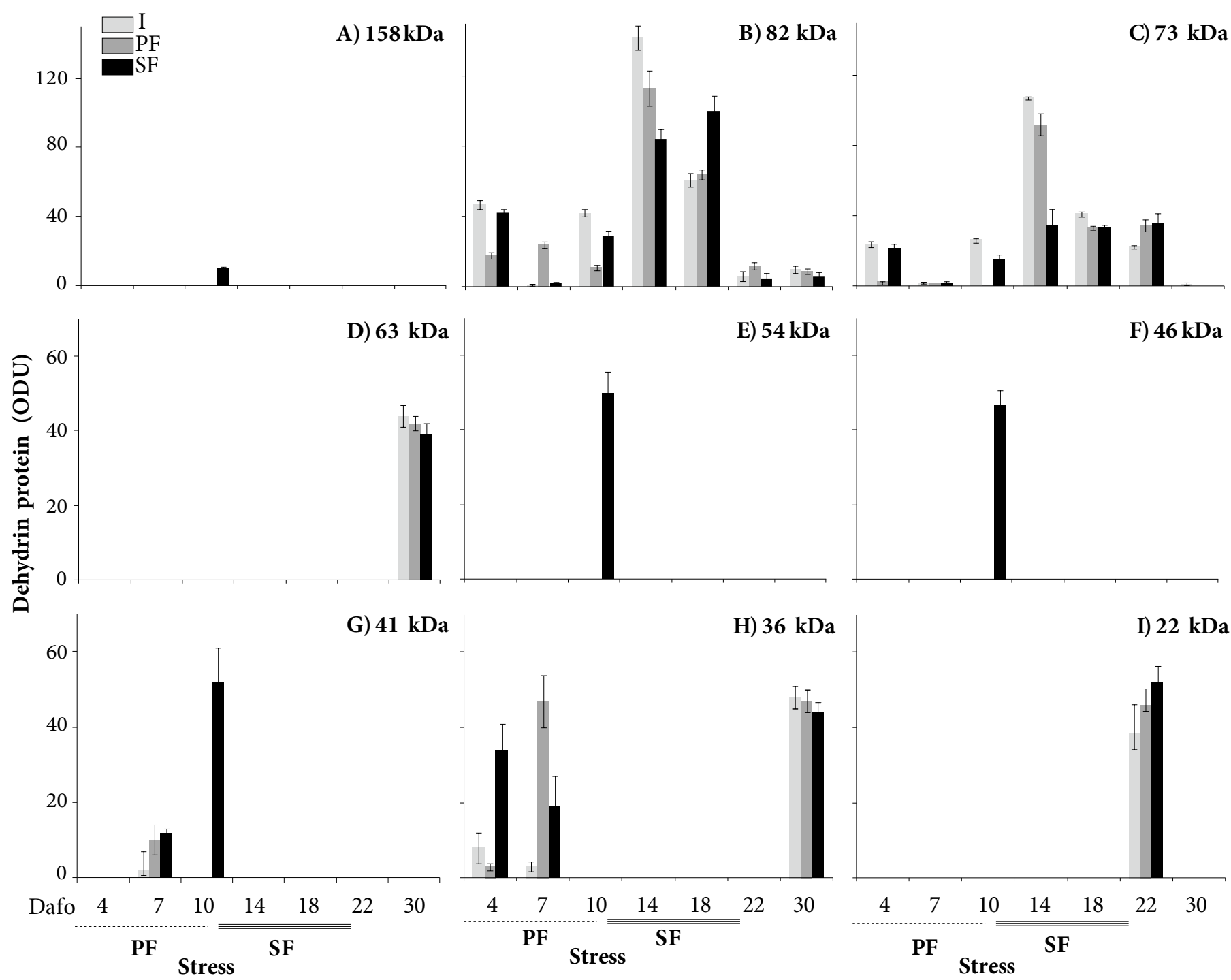

Figure 4. Quantification of dehydrins detected in pods of irrigated and water stressed bean cv. 'Otomi' plants. Dehydrin content in protein extracts of bean pods (Figure 3) from irrigated (I) or drought-stressed plants at pod formation (PF) or seed filling (SF) stages, was quantified by densitometry, and then graphs were constructed. Each graph represents the data for one dehydrin identified by its size in kiloDaltons ( $\mathrm{kDa})$. ODU: Optical density units/mm². Vertical line on the bars are standard errors $(n=3)$.

is necessary to define if some of the dehydrins present in $\mathrm{cv}$. 'Otomi' are the result of genetic selection for arid highlands. It would then be possible to use them as selection markers for drought resistance cultivars.

\section{CONCLUSIONS}

Drought stress applied at stages of pod formation and seed filling had a stronger effect on seed yield than when applied in previous stages of bean development. Nine different dehydrins were observed in leaves and pods of common bean cv. 'Otomí. Two dehydrins of 82 and 73
$\mathrm{kDa}$ were detected in leaves and pods, throughout all the studied vegetative and reproductive stages of development, either with or without water stress. These results suggest the proteins found are constitutive dehydrins in this cultivar. Expression profiles, done early in water deprivation treatments, for leaves at seedling and seed filling and pods at seed filling, indicate that these two dehydrins might play also a relevant protective role against drought at seedling development and seed formation. Dehydrins of 63, 36, and $22 \mathrm{kDa}$ were highly expressed at the end of the SF stage in irrigated and water-stressed plants, probably as means of acquiring desiccation tolerance in seeds. 


\section{ACKNOWLEDGMENTS}

HLT wants to acknowledge the grant DGAPA-UNAM, IN225001 that partially supported this work.

\section{BIBLIOGRAPHY}

Acosta D. E., R. M. D. Amador y G. J. A. Acosta (2003) Abscisión de estructuras reproductoras en frijol común bajo condiciones de secano. Agricultura Técnica en México 29:155-168.

Bhattarai T. and S. Fettig (2005) Isolation and characterization of a dehydrin gene from Cicer pinnatifidum, a drought-resistant wild relative of chickpea. Physiologia Plantarum 123:452-458.

Borovskii G. B., I. V. Stupnikova, A. I. Antipina, S. V. Vladimirova and V. K. Voinikov (2002) Accumulation of dehydrin-like proteins in the mitochondria of cereals in response to cold, freezing, drought and ABA treatment. BMC Plant Biology 2:5. Online: http://www.ncbi.nlm.nih.gov/pmc/articles/PMC116594/ pdf/1471-2229-2-5.pdf (September 2011).

Bradford M. M. (1976) A rapid and sensitive method for the quantitation of microgram quantities of protein utilizing the principle of protein-dye binding. Analytical Biochemistry 72:248-254.

Brini F., W. Saibi, I. Amara, A. Gargouri, K. Masmoudi and M. Hanin (2010) The wheat dehydrin DHN-5 exerts a heat-protective effect on beta-glucosidase and glucose oxidase activities. Bioscience Biotechnology and Biochemistry 74:1050-1054.

Castellanos J. Z., S. X. B. Uvalle y A. Aguilar (2000) Manual de Interpretación de Análisis de Suelos y Aguas. 2da. ed. Colección INCAPA. San Miguel de Allende Gto. 226 p.

Chatelain E., M. Hundertmark, O. Leprince, S. L. Gall, P. Satour, S. Deligny-Penninck, H. Rogniaux and J. Buitinik (2012) Temporal profiling of the heat-stable proteome during late maturation of Medicago truncatula seeds identifies a restricted subset of late embryogenesis abundant proteins associated with longevity. Plant Cell and Environment 35:1440-1445.

Close T. J. (1996) Dehydrins: emergence of biochemical role of a family of plant dehydration proteins. Physiologia Plantarum 97:795-803.

Close T. J., R. D. Fenton and F. Moonan (1993) A view of plant dehydrins using antibodies specific to the carboxy terminal peptide. Plant Molecular Biology 23:279-286.

Close T. J., A. A. Kortt and P. M. Chandler (1989) A cDNA-based comparison of dehydration-induced proteins (dehydrins) in barley and corn. Plant Molecular Biology 13:95-108.

Colmenero-Flores J. M., F. Campos, A. Garciarrubio and A. A. Covarrubias (1997) Characterization of Phaseolus vulgaris cDNA clones responsive to water deficit: identification of a novel late embryogenesis abundant-like protein. Plant Molecular Biology 35: 393-405.

Colmenero-Flores J. M., L. P. Moreno, C. E. Smith and A. A. Covarrubias (1999) Pvlea-18, a member of a new late embryogenesisabundant protein family that accumulates during water stress and in the growing regions of well-irrigated bean seedlings. Plant Physiology 120:93-104

Cuellar-Ortiz S. M., M. P. Arrieta-Montiel, J. Acosta-Gallegos and A. A. Covarrubias (2008) Relationship between carbohydrate partitioning and drought resistance in common bean. Plant Cell and Environment 31:1399-1409.

De la Fuente M., A. Borrajo, J. Bermúdez, M. Lores, J. Alonso, M. López, M. Santalla, A. M. De Ron, C. Zapata and G. Álvarez (2011) 2-DE-based proteomic analysis of common bean (Phaseolus vulgaris L.) seeds. Journal of Proteomics 74:262-267.

FAO (2005) FAOSTAT Statistical Database Food and Agriculture Organization of the United Nations. FAO. http://faostat.fao.org/default.htm. (September 2008).

Fernández F., P. Gepts y M. López (1991) Etapas de desarrollo en la planta de frijol. En: Frijol: Investigación y Producción. López M, F Fernández, A van Schoonhoven (eds). Centro Internacional de Agricultura Tropical (CIAT). Cali, Colombia. pp:61-78.

Gebeyehu S., H. Wiese and S. Schubert (2010) Effects of drought stress on seed sink strength and leaf protein patterns of common bean genotypes. African Crop Science Journal 18:75-88.
González R. H. and R. Bernsten (2005) Adoption of improved bean varieties in the semiarid highlands of México. In: Annual Report of the Bean Improvement Cooperative. J Beaver, J Kelly, P Miklas, S J Park, H F Schwartz, B Vandenberg, K Kmiecik, C Kkurowski, J Myers, R Riley, A D Ron (eds). BIC. Michigan State University 48:60-61.

Guida D. S. M., R. Vasconcelos R., R. F. De Oliveira and C. Pimentel (2004) Gas exchange and yield response to foliar phosphorus application in Phaseolus vulgaris L. under drought. Brazilian Plant Physiology 16:171-179.

Hanin M., F. Brini, Ch. Ebel, Y. Toda, S. Takeda and K. Masmoudi (2011) Plant dehydrins and stress tolerance. Versatile proteins for complex mechanisms. Plant Signaling and Behavior 6:1503 1509 .

Hu L., Z. Wang, H. Du and B. Huang (2010) Differential accumulation of dehydrins in response to water stress for hybrid and common bermudagrass genotypes differing in drought tolerance. Journal of Plant Physiology 167:103-109.

Insunza I. M. A., V. E. A. Catalán, C. M. Villa, C. I. Sánchez y L. A. Román (2010) Respuesta de la conola al déficit hídrico del suelo. Revisa Fitotecnia Mexicana 33:53-59.

Jiménez-Bremont, J. F., I. Maruri-López, A. E. Ochoa-Alfaro, P. Delgado-Sánchez, J. Bravo and M. Rodríguez-Kessler (2013) LEA Gene Introns: is the intron of dehydrin genes a chacaterístic of the serine-segment? Plant Molecular Biology Reporter 31:128 140.

Jones A. L. (1999) Phaseolus bean: Post-harvest operations. Edited by AGSI/FAO: Mejia D. and Lewis B. Centro Internacional de Agricultura Tropical (CIAT). pp:1-24. Online: http://www.fao. org/fileadmin/user_upload/inpho/docs/Post_Harvest_Compendium_Phaesolus_beans.pdf. (0ctober 2012).

Laras A. E., E. S. Sandi and R. P. Dyah (2013) Protein profiles and dehydrin accumulation in some soybean varieties (Glycine max $\mathrm{L}$ Merr) in drought stress conditions. American Journal of Plant Sciences 4:134-141

Liang D., H. Xia, S. Wu and F. Ma (2012) Genome-wide identification and expression profiling of dehydrin gene family in Malus do mestica. Molecular Biology Reports 39:10759-10768.

López C. G., G. M. Banowetz, C. J. Peterson and W. E. Kronstad (2002) Wheat dehydrin accumulation in response to drought stress during anthesis. Functional Plant Biology 29:1417-1425.

Martínez G. M. A., E. S. Osuna C., J. S. Padilla R., J. A. Acosta y C. Loredo O. (2008) Tecnología para la Producción de Frijol en el Norte Centro de México. Book 4. San Luis CIRNE-INIFAP. $206 \mathrm{p}$.

Miklas P. N., J. D. Kelly, S. E. Beebe and M. W. Blair (2006) Common bean breeding for resistance against biotic and abiotic stresses: from classical to MASS breeding. Euphytica 147:105-131.

Miyashita K., S. Tanakamaru, T. Maitani and K. Kimura (2005) Recovery responses of photosynthesis, transpiration, and stomatal conductance in kidney bean following drought stress. Environ mental and Experimental Botany 53:205-214.

Mouillon J. M., S. K. Eriksson and P. Harryson (2008) Mimicking the plant cell interior under water stress by macromolecular crowding: disordered dehydrin proteins are highly resistant to structural collapse. Plant Physiology 148:1925-1937.

Neslihan O. Z., V. Talamé, M. Deyholos, Ch. B. Michalowski, D. W. Galbraith, N. Gozukirmizi, R. Tuberosa and H. J. Bohnert (2002) Monitoring large-scale changes in transcript abundance in drought- and salt-stressed barley. Plant Molecular Biology 48:551-573.

Nuñez B. A., G. Hoogenboom and D. S. Nesmith (2005) Drought stress and distribution of vegetative and reproductive traits of a bean cultivar. Scientia Agricola 62:18-22.

OEIDRUS (2011) Anuario Estadístico de Productos Agrícolas. Online: http://www.oeidrus-jalisco.gob.mx/agricultura/anuarios/ (April 2013).

Olvera-Carrillo Y., F. Campos, J. L. Reyes, A. Garcia R. and A. A. Covarrubias (2010) Functional analysis of the group 4 late embryogenesis abundant proteins reveals their relevance in the adaptive response during water deficit in Arabidopsis. Plant Physiology 154:373-390.

Rodríguez D. A. M., M. T. García C. and J. L. Muñoz S (2003) Análisis bioquímico y fisiológico de Fouquieria splendens ssp. breviflora 
bajo la acción de agentes de estrés hídrico. Polibotánica 16:4962.

Rorat T. (2006) Plant dehydrin-tissue location, structure and function. Cellular and Molecular Biology Letters 11:536-556.

Saladin G., C. Magné and C. Clément (2003) Stress reactions in Vitis vinifera $\mathrm{L}$. following soil application of the herbicide flumioxazin. Chemosphere 53:199-206.

Schneider K. A., R. Rosales-Serna, F. J. Ibarra-Pérez, B. Cazares-Enríquez, J. A. Acosta-Gallegos, P. Ramírez-Vallejo, N. Wassimi and J. D. Kelly (1997) Improving common bean per formance under drought stress. Crop Science 37:43-50.

Shinozaki K. and K. Yamaguchi-Shinozaki (2007) Gene networks involved in drought stress response and tolerance. Journal of Experimental Botany 58:221-227.

Sun X., D. H. Xi, H. Feng, J. B. Du, T. Lei, H. G. Liang and H. H. Lin (2009) The dual effects of salicylic acid on dehydrin accumulation in water-stressed barley seedlings. Russian Journal of Plant Physiology 56:3488-3594.

Towbin M., T. Staehelin and J. Gordon (1979) Electrophoretic transfer of proteins from polyacrylamide gels to nitrocellulose sheets: procedure and some applications. Proceedings of the National Academy of Sciences USA 76:4350-4354

Tripepi M., M. Pöhlschroder and M. B. Bitonti (2011) Diversity of dehydrins in Oleae europaea plants exposed to stress. The Open
Plant Science Journal 5:9-13.

Tunnacliffe A. and M. J. Wise (2007) The continuing conundrum of the LEA proteins Naturwissenschaften 94:791-812.

Turco E., T. J. Close, R. D. Fenton and A. Ragazzi (2004) Synthesis of dehydrin-like proteins in Quercus ilex L. and Quercus cerris $\mathrm{L}$. seedlings subjected to water stress and infection with Phytophthora cinnamomi. Physiological and Molecular Plant Patho$\log y$ 65:137-144

Volaire F., G. Conéjero and F. Leliévre (2001) Drought survival and dehydration tolerance in Dactylis glomerata and Poa bulbosa. Australian Journal of Plant Physiology 28:743-754.

Wechsberg G. E., C. M. Bray and R. J. Probert (1994) Expression of "dehydrin-like" proteins in orthodox seeds of Ranunculus sceleratus during development and water stress. Seed Science Research 4:241-246.

Xue G. P., C. L. McIntyre, D. Glassop and R Shorter (2008) Use of expression analysis to dissect alteration in carbohydrate metabolism in wheat leaves during drought stress. Plant Molecular Biology 67: 197-214

Yang Y., M. He, Ziguo Z., S. Li, Y. Xu, Ch. Zhang, S. D. Singer and Y. Wang (2012) Identification of the dehydrin gene family from grapevine species and analysis of their responsiveness to various forms of abiotic and biotic stress. BMC Plant Biology 12:140-157. 